\title{
JOURNAL.RU
}

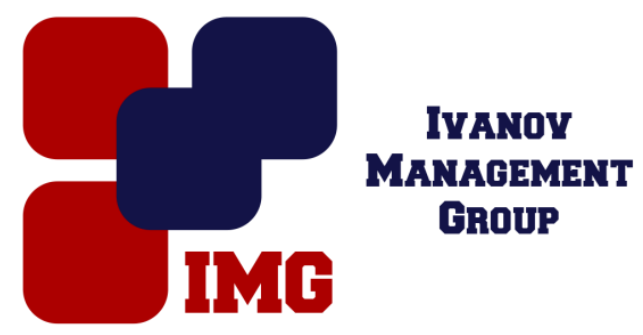

Гордиенко О.В.

doi: $10.18411 / 1 \mathrm{j}-30-04-2017-3-12$

idsp 000001:1j-30-04-2017-3-12

\section{Преимущества и недостатки альтернативных форм разрешения предпринимательскихспоров}

Традиционно в российской правовой действительности суду отводится главная роль «защитника» нарушенных прав. Конституция Российской Федерации каждому гарантирует судебную защиту прав и свобод. Правосудие это осуществляемая в определенном процессуальном порядке деятельность государственного органа - суда. Она выражается в рассмотрении и разрешении споров, вызванных нарушением норм любой существующей отрасли права. Таким образом, судебная защита - это форма разрешения конфликта, основанная на тесной связи и зависимости от государственной власти.

Альтернативные формы разрешения споров- это альтернатива правосудию. Понятие «альтернативные формы разрешения конфликтов» известно достаточно давно и на сегодняшний день применяется часто, однако в юридической науке не сложилось единого четкого подхода в понимании его сущности и содержания. Существует множество определений данному термину, но как наиболее общее из них можно привести следующее: «это преодоление разногласий и противоборств с помощью альтернативных (негосударственных) форм».Основными известными такими формами являются переговоры, медиация, третейский суд, организация процессов в общественных судах (минисуд), независимая экспертиза, нейтральная оценка.

Сложившаяся практика свидетельствует о том, что судебное разбирательство далеко не всегда является эффективным способом решения проблемы, а некоторые обстоятельства, обусловленные современными реалиями, побуждают искать новые, более выгодные и приемлемые способы. Судья исследует доказательства, приведенные сторонами, и, руководствуясь 
нормами закона, принимает решение, имеющее обязательную для обеих сторон силу; он не имеет основной цели мирно урегулировать спор, добиться взаимопонимания и компромисса; в суде всегда будет выигравшая сторона и проигравшая. При использовании альтернативного способа, конфликт разрешается иными действиями, целью которых является именно урегулирование конфликта на взаимовыгодных для обеих сторон условиях.

Предприниматели понимают, что суды перегружены, их ждут длительные судебные тяжбы, которые приведут к значительным финансовым издержкам. Если сфера деятельности хозяйствующего субъекта имеет узкую специфическую направленность, вполне вероятна недостаточная компетентность судей при рассмотрении данного дела. Так же, ввиду принципа публичности судебного разбирательства, некоторые субъекты предпринимательства не хотели бы допустить широкого освещения сложившегося конфликта.«Поэтому представляется, что путь создания альтернативных форм разрешения споров и конфликтов, действующих наряду с судебной формой защиты прав, является сегодня для Россия приемлемым в решении накопившихся проблем судопроизводства».

Стремление сторон исчерпать конфликт без вмешательства государства в лице суда, «сесть за стол переговоров», обговорить взаимовыгодные условия и обоюдно выбрать наиболее подходящее решение, минимизируя при этом финансовые и временные затраты, - все это характерно для альтернативного урегулирования конфликтной ситуации эффективно и быстро, что является его огромным преимуществом и делает перспективным.

Процедура урегулирования, весь ее ход и результаты полностью находится под контролем сторон. Они сами добровольно выбирают конкретную альтернативную форму (переговоры, третейский суд или другое);при проведении процедуры медиации, например, в соглашении сами определяют конкретного привлекаемого специалиста, а так же сроки и порядок проведения. Кстати говоря о сроках, необходимо отметить, что срок урегулирования спора внесудебными способами намного меньше, чем в суде. Так, например, путем проведения переговоров, можно решить сложившийся конфликт в течение нескольких дней, что очень выгодно для хозяйствующего субъекта, так как у него появится возможность как можно скорее продолжить дальнейшую работу и, в случае сохранения нормальных деловых связей, продолжить сотрудничество со своим оппонентом. Отсутствие властного государственного органа свидетельствует об отсутствии жестких обязательных процессуальных правил 
проведения альтернативных процедур. Напротив, они простые и неформальные. Так же, для внесудебных форм разрешения споров не характерен принцип гласности, а характерен принцип соблюдения частого характера, поэтому вся информация, касающаяся конфликта, останется между сторонами и привлекаемым специалистом (медиатором, арбитром, независимым экспертом), что позволит сохранить нормальную репутацию субъектов предпринимательской деятельности.

Альтернативное урегулирование в почти любом случае заканчивается решением, основанном на обоюдном согласии, обе стороны должны быть удовлетворены исходом. Исключение составляет третейское разбирательство, по итогам которого третейский судья выносит обязательное для сторон решение, так как они принимают на себя обязанность добровольно исполнять его и прилагают усилия к тому, чтобы оно было юридически исполнимо.

В любом случае, когда стороны решают прибегнуть к какой-либо альтернативной процедуре, они не несут никаких рисков, для них ситуация хуже не станет, а в любой момент они могут отказаться от дальнейшего продолжения.

Помимо всех перечисленных достоинств внегосударственного урегулирования, оно имеет и определенные недостатки. Так, для мирного разрешения спора обязательно необходимо желание завершить конфликт как можно скорее и на взаимовыгодных условиях. Если одна из сторон настроена враждебно, не согласна взаимодействовать с оппонентом, считая его своим непримиримым соперником, и хочет добиться удовлетворения только своих интересов, в этом случае применение альтернативных процедур бессмысленно и бесполезно, положительного эффекта добиться будет невозможно и спор останется неразрешенным. «Для успешного ведения переговоров с участием посредника необходимо, чтобы стороны...делились необходимой для разрешения ситуации информацией, были гибкими, ...осознавали свои истинные интересы и могли отличить их от сиюминутных желаний, предвидели последствия в случае срыва переговоров, были способны сформулировать реалистичное, выполнимое, долгосрочное соглашение, удовлетворяющее все стороны, и т. д.».

Если конфликт сложился между несколькими субъектами предпринимательской деятельности (3-4 и более), добиться согласования воли каждого будет очень сложно, а скорее невозможно. В данном случае переговоры однозначно неэффективны, а необходимо привлечение независимого 
посредника, который смог бы скоординировать усилия всех участников, чтобы добиться консенсуса.

Применение внесудебных процедур более актуально при незначительных спорах, например, когда речь идет о небольших суммах или об установлении фактов.

Недостатком альтернативных процедур с привлечением независимых третьих лиц (медиаторов, посредников, экспертов)является нехватка компетентных специалистов, способных создать необходимые условия для эффективного разрешения конфликта.

Непопулярность в использовании альтернативных приемов среди населения нашего государства объясняется недостаточной информированностью об их сущности, о конкретных видах и их специфике, о преимуществах и недостатках по сравнению с государственными, а так же нехваткой специалистов. Однако будет справедливым отметить, что при проведении пропагандистской работы альтернативные процедуры имеют серьезные шансы на успех. Не подменяя правосудия, но при этом имея перед ним значительные преимущества, альтернативные процедуры, благодаря своей высокой эффективности, экономности и гибкости, помогут урегулировать спор на наиболее выгодных для обеих сторон условиях, что позволит сохранить и укрепить нормальные деловые связи.

1. Верховская В. А., Воскресенская В. А., «Альтернативные методы разрешения конфликтов в странах различных правовых семей, Вестник СПбГУ. Сер. 17. Философия. Конфликтология. Культурология. Религиоведение. 2016. Вып. 1

2. Кудрявцев В.В. Разрешение споров третейским судом // Экономика и социум. - 2015. №1 (14).

3. Сулакшин С.С., Буянова Е.Э. «Альтернативные способы разрешения споров между субъектами предпринимательской деятельности», Москва Научный эксперт, 2015.

4. Тихонова О.С. «Альтернативные способы разрешения споров в практике предпринимательской» // Современные научные исследования и инновации. 2012. № 5.

5. Худойкина Т.В. Перспективы развития альтернативного разрешения правовых споров и конфликтов в регионах Российской Федерации // Регионология. - 2005. - № 4.

6. Худойкина Т.В. Применение посредничества как примирительной процедуры при разрешении правовых споров и конфликтов в России // Социально-политические науки. 2012. - №4. 